\title{
O ENSINO DE GEOLOGIA E A PROFISSÃo DE GEÓLOGO
}

Nos últimos anos o notável renascimento da profissão de geologia no Brasil acompanhou a retomada do desenvolvimento econômico, interrompendo os efeitos da chamada "década perdida". O fato fez as universidades se organizarem para formar mais geólogos diante da grande demanda, por empresas, órgãos de governo e agentes públicos. Os desafios enfrentados pelos geólogos integram variadas facetas do desenvolvimento social e econômico do país, mas o espaço profissional que a ele compete tem sido disputado de vários modos. A importação pura e simples de geólogos de outros países para suprir a momentânea falta de geólogos é desnecessária. As universidades brasileiras demonstraram capacidade de enfrentar com sucesso a missão. É preciso ampliar expectativas e aumentar a união e a determinação, em busca do fortalecimento dos cursos atuais.

O aparecimento de novos cursos de graduação depende de existirem condições adequadas para pleno funcionamento, já que os desafios são múltiplos: reunir corpo docente de alto nível, adquirir equipamentos, veículos de campo e laboratórios e implantar a infra-estrutura mínima para que aulas e atividades aconteçam com naturalidade e eficácia. Terræ Didatica pode contribuir nesse campo, como suporte de difusão de experiências e práticas educativas.

Desde os anos 1960, a esmagadora maioria dos cursos brasileiros de Geologia continua a ser mantida por universidades públicas. A acelerada privatização do ensino superior nas últimas décadas levou à proliferação de cursos superiores, verdadeiras "máquinas de fazer dinheiro" em escolas privadas. Salvo diversas e bem-conhecidas exceções, a educação tornou-se um modelo de negócio, sobrepondo-se à missão institucional. Nenhum novo curso de Geologia é mantido por instituição particular, mas a possibilidade não está afastada, se prosseguir o incremento da demanda por geólogos, gerando pressões em exames vestibulares das universidades tidas como de referência.

O geólogo tem diante de si o desafio de ajudar a sociedade a conhecer melhor o mundo em que pisamos, sua origem e evolução. A crescente concentração urbana exige capacidade de atuar em campos aplicados à engenharia, meio ambiente e hidrogeologia. Os efeitos de certas catástrofes naturais podem ser minimizados, caso conhecimentos elementares da dinâmica natural - sob o ponto de vista da Geologia fossem devidamente levados em conta pelas autoridades competentes. 0 processo de conscientização, também chamado de "alfabetização nas ciências da natureza", contudo, é lento e depende de muitas variáveis: uma delas é de geólogos profissionalmente bem preparados. Além dessas dificuldades, não temos percebido a importância da difusão desse campo da Ciência na escola básica. A educação em escolas de nível médio e fundamental não desenvolve uma compreensão ampla de como o planeta funciona, condição que ajuda a preparar crianças, jovens e adultos para o pleno exercício da cidadania e contribui para diminuir desigualdades. 
Entre os anos 1950-1960 o aprendizado de Geologia fora impulsionado pelo Estado, que criou bem-sucedida Campanha de Formação de Geólogos (CAGE). Desde então, os cursos de graduação e pós-graduação se fortaleceram, mas enfrentam dificuldades de toda ordem. Temos 0 orgulho de contar com grandes mestres e a competência nacional tem sido internacionalmente elogiada e valorizada. Amadurecida, a Geologia exibe notável vigor no Brasil, como ciência e como profissão, fato comprovado nas inúmeras reu-niões, simpósios e congressos técnico-científicos. O território, contudo, está longe de ser mapeado e conhecido nos níveis atingidos por países mais desenvolvidos. A reposição de docentes é necessidade permanente: exigem-se novos mestres, capazes de contagiar os jovens de todas as idades que se aventuram a estudar Geologia. Para praticar Geologia, é preciso dispor de sólida base científica, pleno domínio de técnicas e uma certa dose de talento. A profissão é peculiar, porque os desafios e exigências para o aprendizado e exercício profissional são igualmente distintos de outras profissões de nível superior. Os estudantes, com seu típico entusiasmo e alegria, reconhecem o fato. Sabemos dar valor ao campo, o lugar onde se aprende Geologia. A brincadeira de que "Geologia se aprende pelos pés", reflete a noção de que, quanto mais o geólogo caminha e percorre diferentes locais, mais aprimora sua capacidade de integrar informações e gerar conhecimento novo.

O Estado, a quem cabe a função de regular a preparação profissional, ainda não definiu, no caso da Geologia, as diretrizes curriculares, causando preocupação. Para ajudar a minimizar o problema, neste volume publicamos a versão corrigida e atualizada das Diretrizes Curriculares aprovadas pelo Fórum Nacional de Cursos de Geologia, acompanhada de relatos de reuniões dessa entidade, entre 2006 e 2007.

\section{A revista}

Terræ Didatica, no volume 4, persegue a ideia de ser veículo de comunicação geocientífica da comunidade íbero-latino-americana, graças à colaboração de pesquisadores de universidades brasileiras e do exterior.

O volume é integrado por contribuições de autores da Bahia, Paraná e Rio Grande do Sul. Duas delas descrevem ricas experiências e caminhos percorridos em diferentes disciplinas de curso de graduação em Geologia: "Estratégia didática clássica aplicada à disciplina Geologia Introdutória do curso de Geologia da Universidade Federal da Bahia" e "Ensino de técnicas de análises de minerais com ênfase na interpretação de dados: teoria e prática na formação do geólogo". Outro artigo organiza informações e descreve uma classe mineralógica bastante especial e rara: a das "combinações orgânicas associadas ao hidrogênio".

Reproduzimos, ainda, conferências do 10 Simpósio de Pesquisa em Ensino e História de Ciências da Terra, e III Simpósio Nacional sobre Ensino de Geologia no Brasil, eventos realizados em Campinas, em setembro de 2007. Como as apresentações não integram os anais dos eventos, decidimos publicá-las neste volume e no próximo, tanto pela importância quanto pelo valor das concepções expostas. A primeira, "Perspectivas 
actuais sobre o ensino das ciências: clarificação de caminhos", analisa as bases teóricas de diferentes concepções de ensino de Ciências. O autor argumenta que, nas conexões interdisciplinares entre educação e ciências, a metodologia de ensino e a pesquisa assumem grande importância. Em "Recursos Geoambientais y ciudadania", o autor expõe as bases de um projeto de pesquisa que procura valorizar a articulação entre universidade e comunidade, utilizando estratégias de formação de cidadania por intermédio de intervenções nas relações entre a sociedade e a natureza. Esperamos que a leitura dos textos seja proveitosa e estimule leitores e autores a contribuir ainda mais com as próximas edições. 